\title{
Modification of Sertoli cell functions in vitamin A-deficient rats
}

\author{
H. F. S. Huang*†, S. Gould* and A. V. Boccabella $\dagger$ \\ ${ }^{*}$ Department of Medicine, V.A. Medical Center, East Orange, New Jersey 07019, USA; and \\ $\dagger$ Department of Anatomy, University of Medicine and Dentistry of New Jersey, New Jersey \\ Medical School, 185 South Orange Avenue, Newark, New Jersey 07103-2757, USA
}

\begin{abstract}
Summary. FSH binding and cAMP responses to FSH in Sertoli cell-enriched testes were not affected by the vitamin A (retinol) status of the animals. These results indicate that changes in Sertoli cell functions during vitamin A deficiency are independent of FSH-Sertoli cell interactions. Concentrations of serum androgen binding protein (ABP) in vitamin A-deficient rats were consistently higher than those of control animals throughout the study period. The accumulation of testicular fluid after efferent duct ligation, an indication of Sertoli cell secretory function, was normal in vitamin Adeficient rats at least until 70 days of age, but declined thereafter. ABP concentrations in seminiferous tubular fluid of vitamin A-deficient rats increased transitorily during the 70-80-day age period but returned to normal by 90 days. The increment of ABP in seminiferous tubular fluid after efferent duct ligation, and ABP concentrations in interstitial fluid were consistently lower in vitamin A-deficient rats. The higher serum ABP in vitamin A-deficient rats therefore cannot be explained by an increase in the permeability of Sertoli-cell tight junctions or basement membrane.
\end{abstract}

Keywords: vitamin A; Sertoli cell; androgen binding protein; seminiferous tubule; FSH; cAMP

\section{Introduction}

The requirement of vitamin A (retinol) for spermatogenesis is well documented (Thompson et al., 1964; Huang \& Hembree, 1979) but the mechanisms responsible for this need remain unexplored. Recent studies have demonstrated that Sertoli cell tight junctions of rats became leaky during chronic vitamin A deficiency (Unni et al., 1983; Huang et al., 1988). These observations suggest altered Sertoli cell membrane properties which could prevent normal FSH-Sertoli cell interactions, or Sertoli cell secretory functions. Either of these could disturb the normality of the seminiferous epithelial environment and thereby cause severe germ cell loss during chronic vitamin A deficiency (Setchell \& Waites, 1975; Huang et al., 1988).

This study examined the effect of vitamin A deficiency upon interactions between FSH and Sertoli cells, as well as its effect on Sertoli cell secretory functions.

\section{Materials and Methods}

\section{Animals}

Vitamin A deficiency was induced in male rats by the method described previously (Huang \& Hembree, 1979). Briefly, 20-day-old weanling male Sprague-Dawley rats were fed a diet free of vitamin A alcohol (retinol) (ICN Nutritional Biochemical, Cleveland, OH, USA). The diet was subsequently supplemented with retinoic acid $(10 \mathrm{mg} / \mathrm{kg})$ after the rats attained 70 days of age (Huang \& Hembree, 1979). The control animals were fed the vitamin A-deficient diet supplemented with retinyl acetate $(6 \mathrm{mg} / \mathrm{kg})$. The serum and testicular vitamin $A$ status, and the 
regression of spermatogenesis in animals fed these diets, have been reported (Huang \& Marshall, 1983; Huang et al., 1988).

\section{Experiment 1}

Sertoli cell secretory function. Beginning at 40 days of age and every 10th day thereafter, groups of animals were subjected to unilateral efferent duct ligation through a midline incision. The testis-epididymis complex was returned to the scrotum after the operation. Animals were bled through the retro-orbital sinus $20 \pm 1 \mathrm{~h}$ after operation and were killed.

The weights of both testes were recorded immediately after the dissection. The weight increase in the ligated testis over the contralateral unligated testis was taken as an indicator for Sertoli cell secretory function (Setchell \& Waites, 1975).

Collection of interstitial fuid and seminiferous tubular fuid. The interstitial fluid and seminiferous tubular fluid were collected from both testes according to the procedure described by Turner et al. (1984). The fluids were stored at $-30^{\circ} \mathrm{C}$ and were used for the measurement of lactate and androgen binding protein. The concentrations of testosterone and androgen binding protein in seminiferous tubular fluid of 20 normal adult rats were comparable to those reported by others using the same method or by micropuncture (Turner et al., 1984).

Androgen binding protein measurement. Androgen binding protein (ABP) concentrations in serum, seminiferous tubular fluid and interstitial fluid were determined by radioimmunoassay (Gunsalus et al., 1978) using reagents provided by NIADDK. Results were expressed as microliter equivalent of an ABP standard prepared from rat epididymal cytosol (GMB-E-1) (Gunsalus et al., 1978). Each microliter equivalent of ABP corresponds to 0.83 ng rat ABP (WR-R-1). This system has been used in previous studies (Huang et al., 1981, 1985). The sensitivity of the assay is $0.4 \mu \mathrm{leq} /$ tube, and the inter- and intra-assay coefficient of variation were $12 \%$ and $6 \%$, respectively.

Lactate assay. Lactate concentrations in seminiferous tubular fluids were determined by an enzymic method using assay kits provided by Sigma Biochemical Inc. (St Louis, MO, USA). Briefly, 25-50 $\mu$ l of seminiferous tubular fluid was diluted to $0.1 \mathrm{ml}$ with distilled water and mixed with $0.9 \mathrm{ml}$ of reaction solution which contained $40 \mathrm{mg}$ beta $\mathrm{NAD}+, 0.27 \mathrm{ml}$ lactic acid dehydrogenase, $5.75 \mathrm{ml}$ glycine/hydrazine buffer $(0.5 \mathrm{M}$-glycine/ $0.6 \mathrm{M}$-hydrazine sulphate/ $5 \mathrm{~mm}$-EDTA) and $12 \mathrm{ml}$ distilled water. The mixtures were incubated at $37^{\circ} \mathrm{C}$ for $45 \mathrm{~min}$ and the optical density was read at $340 \mathrm{~nm}$. The standard curve was constructed with $1-100 \mathrm{mg}$ lactic acid per $0.1 \mathrm{ml}$ distilled water. The sensitivity of this assay was $2 \mathrm{mg} /$ tube and the intra-assay coefficient of variation was $6-8 \%$.

\section{Experiment 2}

Rats with Sertoli cell-enriched testes were produced by exposing pregnant female rats to $100 \mathrm{R}$ whole-body $\mathrm{X}$-irradiation at the 20th day of gestation (Means et al., 1976). The male offspring were weaned on the 20th day of age and fed either vitamin A-deficient diet or control diet as described above. The rats were killed at various ages. One testis from each animal was fixed in Bouin's solution and processed for regular histology. A portion of the other testis from each animal was used immediately for in-vitro cAMP production. The remaining portion of the same testis was stored at $-80^{\circ} \mathrm{C}$ for subsequent FSH binding assay. Only results obtained from rats with 'Sertoli cell-enriched' testes were included in the present study (Fig. 1).

FSH binding. Rat FSH I-6 (NIADDK) was iodinated by the lactoperoxidase method (Miyachi et al., 1972). The specific activity was $27-30 \mu \mathrm{Ci} / \mu \mathrm{g}$. The specificity of the FSH binding by testicular tissues was verifed by competitive binding of non-radioactive FSH and the dose-dependent increase of FSH bound by a constant amount of testicular tissue.

In the standard binding assay, frozen testicular tissue was homogenized in cold TMB buffer containing Tris- $\mathrm{HCl}$ $(20 \mathrm{~mm}), \mathrm{MgCl}_{2}(10 \mathrm{~mm})$ and $0 \cdot 1 \% \mathrm{BSA}(\mathrm{pH} 7 \cdot 2)$. The homogenates were diluted to a final concentration of $200 \mathrm{mg}$ tissue $/ \mathrm{ml}$. Then $0.1 \mathrm{ml}$ tissue homogenate was incubated with $10 \mu \mathrm{g}$ iodinated FSH (sp. act. $14188 \mathrm{c.p} . \mathrm{m} . / \mu \mathrm{g}$ ) in $0.3 \mathrm{ml}$ TMB buffer at $25^{\circ} \mathrm{C}$ for $22 \mathrm{~h}$. At the end of incubation, $4 \mathrm{ml}$ ice-cold PBS (pH 7.4) were added, and the tubes were centrifuged at $2000 \mathrm{~g}$ for $30 \mathrm{~min}$. The pellets were washed with $4 \mathrm{ml}$ cold PBS and centrifuged. The radioactivity of the pellets was determined in a gamma counter with approximately $80 \%$ counting efficiency. After determination of radioactivity, the pellets were solubilized in $0.5 \mathrm{ml} 0.1 \mathrm{~N} \cdot \mathrm{NaOH}$. Protein concentration of the pellets was determined by the Folin reagent method (Lowry et al., 1951) using bovine serum albumin as standard.

cAMP production. Fresh decapsulated testicular tissues $(75-200 \mathrm{mg})$ were incubated in $1 \mathrm{ml}$ of a $1: 1(\mathrm{v} / \mathrm{v})$ mixture of Ham's F12 and DMEM containing 2 mM-glutamine, 1 mM-gentamycin, $2 \mathrm{~mm}$-1-methyl-3-isobutylxanthine (MIX) and $20 \mu \mathrm{g} \mathrm{FSH}(\mathrm{NIH} \mathrm{S}-8)$ at $32^{\circ} \mathrm{C}$ for $1 \mathrm{~h}$. At the end of incubation, the contents of the incubation tubes were heated at $90^{\circ} \mathrm{C}$ for $15 \mathrm{~min}$ and were centrifuged at $1500 \mathrm{~g}$ for $30 \mathrm{~min}$. The supernatants were collected and stored at $-80^{\circ} \mathrm{C}$ until assay.

cAMP was measured by radioimmunoassay using reagents provided by New England Nuclear, Boston, MA, USA. Briefly, $100 \mu \mathrm{l}$ of diluted samples were mixed with $100 \mu \mathrm{l}$ tracer (containing $\sim 20000$ c.p.m. iodinated-cAMP) and $100 \mu \mathrm{l}$ antiserum and incubated overnight at $2-8^{\circ} \mathrm{C}$. The antigen antibody complexes were precipitated by adding $0.5 \mathrm{ml}$ precipitation enhancer and centrifuged at $1500 \mathrm{~g}$ for $30 \mathrm{~min}$. The radioactivity of pellets was counted in a 

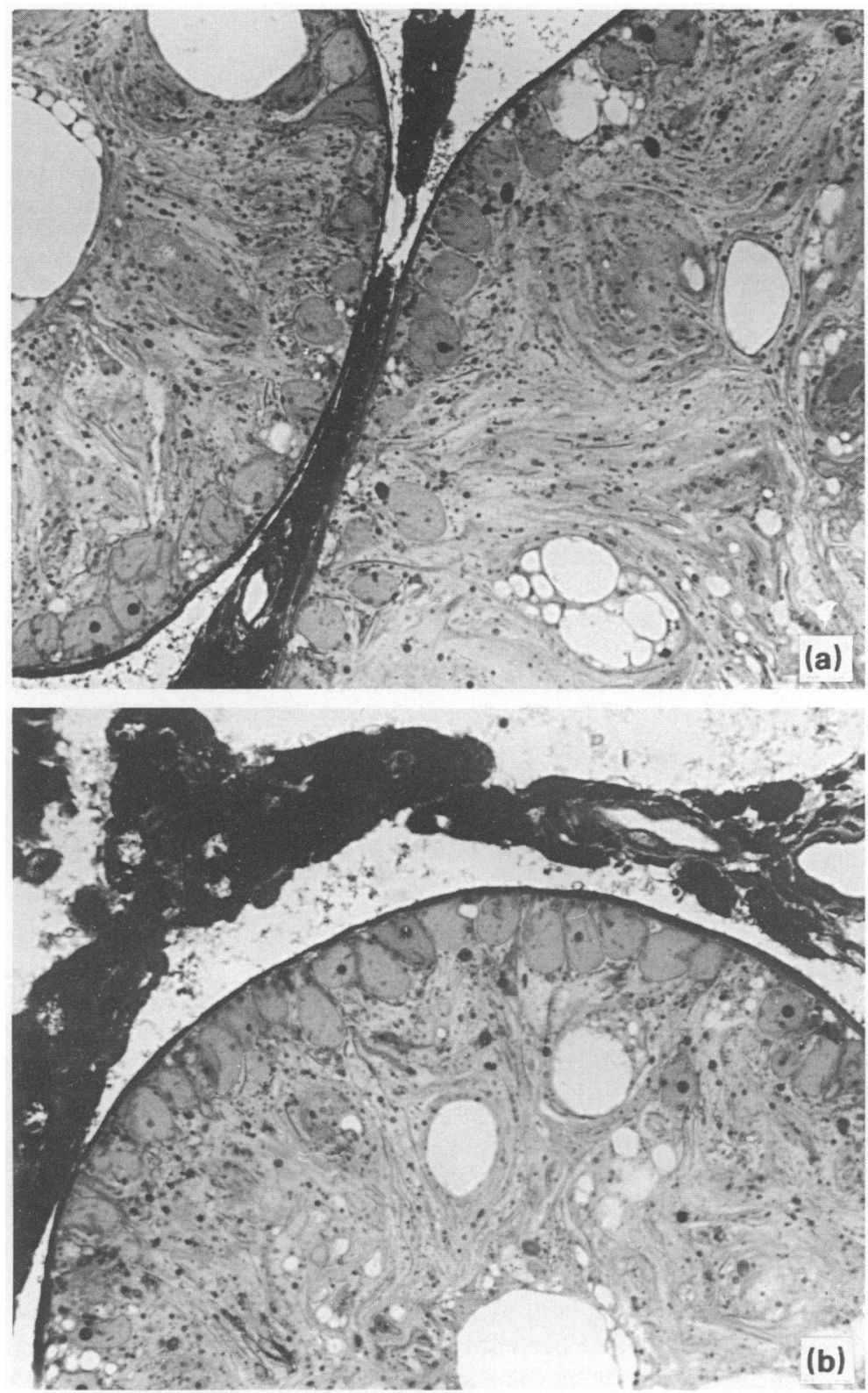

Fig. 1. Photomicrograph of testicular histology of Sertoli cell-enriched rats: (a) 80-day-old control rat; (b) 80-day-old with vitamin-A deficiency. Tissues were fixed by intracardiac perfusion of $20-30 \mathrm{ml}$ saline, followed by $20-30 \mathrm{ml}$ cacodylate-buffered fixative containing $2 \%$ glutaraldehyde $/ 4 \%$ formaldehyde. After postfixation in $\mathrm{OsO}_{4}$ and dehydration in graded ethanol, tissues were embedded in Epon. Sections $(1 \mu \mathrm{m})$ were stained with toluene blue. $\times 350$.

gamma counter. The sensitivity of the assay was $0.5 \mathrm{pmol} /$ tube and the interassay coefficient of variation was $6 \%$. Samples were measured within a 4 day period using the same preparation of reagents.

FSH measurement. Serum FSH concentration was measured by double antibody radioimmunoassay as described by Huang \& Hembree (1979) using reagents (rFSH-I-6, anti-rFSH-S-11 and rFSH-RP2) provided by NIADDK, USA. The intra-assay coefficient of variation was $\sim 6 \%$. 


\section{Statistics}

Student's $t$ test was used to compare values for control animals and those deficient in vitamin A at each time point.

\section{Results}

\section{Experiment 1}

Sertoli cell secretory function. Sertoli cell secretory function, as indicated by the increase of testicular weight $20 \mathrm{~h}$ after efferent duct ligation, was normal in the vitamin A-deficient animals at least until 70 days of age (Table 1). By 80 days, both absolute and percentage weight increment of the testis after efferent duct ligation were lower $(P<0.05)$ in the vitamin A-deficient animals than in the age-matched control animals (Table 1).

Table 1. Testicular weights (mg) of vitamin A-deficient rats before and after efferent duct ligation (EDL)

\begin{tabular}{|c|c|c|c|c|c|c|c|c|}
\hline \multirow[b]{2}{*}{$\begin{array}{l}\text { Age } \\
\text { (days) }\end{array}$} & \multicolumn{4}{|c|}{ Control rats } & \multicolumn{4}{|c|}{ Vitamin A-deficient rats } \\
\hline & $\begin{array}{c}\text { No. of } \\
\text { rats }\end{array}$ & $\begin{array}{l}\text { EDL } \\
\text { testis }\end{array}$ & $\begin{array}{l}\text { Intact } \\
\text { testis }\end{array}$ & $\begin{array}{c}\% \\
\text { Increment } \dagger\end{array}$ & $\begin{array}{c}\text { No. of } \\
\text { rats }\end{array}$ & $\begin{array}{l}\text { EDL } \\
\text { testis }\end{array}$ & $\begin{array}{l}\text { Intact } \\
\text { testis }\end{array}$ & $\begin{array}{c}\% \\
\text { Increment }\end{array}$ \\
\hline 40 & 3 & $1404 \pm 10$ & $1154 \pm 20$ & 22 & 3 & $1452 \pm 63$ & $1161 \pm 33$ & 25 \\
\hline 50 & 4 & $1649 \pm 56$ & $1308 \pm 74$ & 26 & 5 & $1786 \pm 125$ & $1405 \pm 82$ & 27 \\
\hline 60 & 4 & $1916 \pm 85$ & $1478 \pm 68$ & 30 & 5 & $2083 \pm 43$ & $1651 \pm 47$ & 26 \\
\hline 70 & 4 & $2126 \pm 60$ & $1638 \pm 43$ & 30 & 5 & $2115 \pm 62$ & $1702 \pm 21$ & 24 \\
\hline 80 & 4 & $2350 \pm 133$ & $1866 \pm 94$ & 26 & 5 & $1850 \pm 76^{*}$ & $1560 \pm 80^{*}$ & 18 \\
\hline 110 & 4 & $2414 \pm 78$ & $1897 \pm 84$ & 27 & 4 & $1587 \pm 152^{*}$ & $1413 \pm 124 *$ & 12 \\
\hline
\end{tabular}

Values are mean \pm s.e.m. for the no. of rats indicated.

${ }^{*} P<0.05$ compared with value for control rats.

$\uparrow \%$ Increment $=\frac{\text { weight of EDL testis }- \text { weight of intact testis }}{\text { weight of intact testis }}$.

Androgen binding protein. Androgen binding protein (ABP) concentration in seminiferous tubular fluid of the unligated testes of vitamin A-deficient rats was normal at 50 days of age (Table 2). It increased transitorily above the control levels at $70-80$ days $(P<0.01)$, but returned to the control level after 90 days of age.

In normal animals, efferent duct ligation for $20 \mathrm{~h}$ resulted in $70-115 \%$ increase in ABP concentrations in seminiferous tubular fluid. Both absolute and percentage increment of ABP in seminiferous tubular fluid after efferent duct ligation were consistently lower in vitamin A-deficient rats despite the fact that ABP concentrations were sometimes higher in these animals (Table 2).

ABP concentrations in interstitial fluid of intact testes tended to be lower in vitamin A-deficient rats (Table 2). Both the absolute and percentage increments after efferent duct ligation were also lower $(P<0.01)$ in the deficient rats, particularly during the chronic stage of vitamin A deficiency (Table 2).

At all times serum ABP concentrations of vitamin A-deficient rats were higher than those of the control rats (Fig. 2; $P<0.01$ ).

Lactate. Lactate concentrations in seminiferous tubular fluid of vitamin A-deficient rats were normal throughout the experimental period (Table 3 ).

\section{Experiment 2}

Serum FSH. Serum FSH concentrations of vitamin A-deficient rats with Sertoli cell-enriched testes were higher than those of control rats with Sertoli cell-enriched testes at all time points examined $(P<0.01$; Fig. 3$)$. 
Table 2. Androgen binding protein concentrations ( $\mu \mathrm{l}$ eq. GMB-E- $1 / \mathrm{ml}$ ) in seminiferous tubular fluid and interstitial fluid of efferent duct-ligated (EDL) testis and intact testis of control or vitamin Adeficient (VAD) rats

\begin{tabular}{|c|c|c|c|c|c|c|c|}
\hline \multirow[b]{2}{*}{$\begin{array}{l}\text { Age } \\
\text { (days) }\end{array}$} & \multirow[b]{2}{*}{ Treatment } & \multicolumn{3}{|c|}{ Seminiferous tubular fluid } & \multicolumn{3}{|c|}{ Interstitial fluid } \\
\hline & & $\begin{array}{l}\text { Intact } \\
\text { testis }\end{array}$ & $\begin{array}{l}\text { EDL } \\
\text { testis }\end{array}$ & $\begin{array}{c}\% \\
\text { Increment }\end{array}$ & $\begin{array}{l}\text { Intact } \\
\text { testis }\end{array}$ & $\begin{array}{l}\text { EDL } \\
\text { testis }\end{array}$ & $\begin{array}{c}\% \\
\text { Increment }\end{array}$ \\
\hline \multirow[t]{2}{*}{50} & VAD & $\begin{array}{c}12416 \pm \\
777\end{array}$ & $\begin{array}{c}20226 \pm \\
1802\end{array}$ & 65 & - & - & 一 \\
\hline & Control & $\begin{array}{c}12993 \pm \\
493\end{array}$ & $\begin{array}{c}24789 \pm \\
1282\end{array}$ & 98 & - & - & - \\
\hline \multirow[t]{2}{*}{70} & VAD & $\begin{array}{r}17313 \pm \\
3707^{* *}\end{array}$ & $\begin{array}{r}21751 \pm \\
3171^{* *}\end{array}$ & 39 & $\begin{array}{c}3946 \pm \\
439\end{array}$ & $\begin{array}{r}10227 \pm \\
866^{* *}\end{array}$ & 132 \\
\hline & Control & $\begin{array}{c}7647 \pm \\
786\end{array}$ & $\begin{array}{c}15446 \pm \\
691\end{array}$ & 115 & $\begin{array}{c}5546 \pm \\
587\end{array}$ & $\begin{array}{c}19532 \pm \\
4004\end{array}$ & 209 \\
\hline \multirow[t]{2}{*}{80} & VAD & $\begin{array}{r}11857 \pm \\
663^{* *}\end{array}$ & $\begin{array}{r}18914 \pm \\
940^{* *}\end{array}$ & 60 & $\begin{array}{c}3039 \pm \\
612\end{array}$ & $\begin{array}{r}6615 \pm \\
832^{* *}\end{array}$ & 133 \\
\hline & Control & $\begin{array}{c}7414 \pm \\
520\end{array}$ & $\begin{array}{c}13087 \pm \\
942\end{array}$ & 82 & $\begin{array}{c}3898 \pm \\
323\end{array}$ & $\begin{array}{c}18998 \pm \\
5707\end{array}$ & 425 \\
\hline \multirow[t]{2}{*}{90} & VAD & $\begin{array}{l}5857 \pm \\
1156\end{array}$ & $\begin{array}{r}7254 \pm \\
414^{* *}\end{array}$ & 26 & $\begin{array}{c}2918 \pm \\
310\end{array}$ & $\begin{array}{r}2945 \pm \\
685^{* *}\end{array}$ & 1 \\
\hline & Control & $\begin{array}{c}6588 \pm \\
1217\end{array}$ & $\begin{array}{c}14217 \pm \\
1389\end{array}$ & 105 & $\begin{array}{c}3018 \pm \\
625\end{array}$ & $\begin{array}{c}11741 \pm \\
1625\end{array}$ & 385 \\
\hline \multirow[t]{2}{*}{110} & VAD & $\begin{array}{c}8312 \pm \\
1724\end{array}$ & $\begin{array}{c}10478 \pm \\
1747\end{array}$ & 34 & $\begin{array}{c}2870 \pm \\
391\end{array}$ & $\begin{array}{r}3190 \pm \\
520^{* *}\end{array}$ & 18 \\
\hline & Control & $\begin{array}{c}5956 \pm \\
155\end{array}$ & $\begin{array}{c}10120 \pm \\
1456\end{array}$ & 70 & $\begin{array}{c}3734 \pm \\
465\end{array}$ & $\begin{array}{c}12022 \pm \\
1383\end{array}$ & 232 \\
\hline
\end{tabular}

Values are mean \pm s.e.m. for 4 rats/group.

$* \%$ Increment $=($ value of EDL testis - value of intact testis $) /$ value of intact testis. Results are presented as means of the animals used for each time point.

${ }^{* *} P<0.01$ compared with control values.

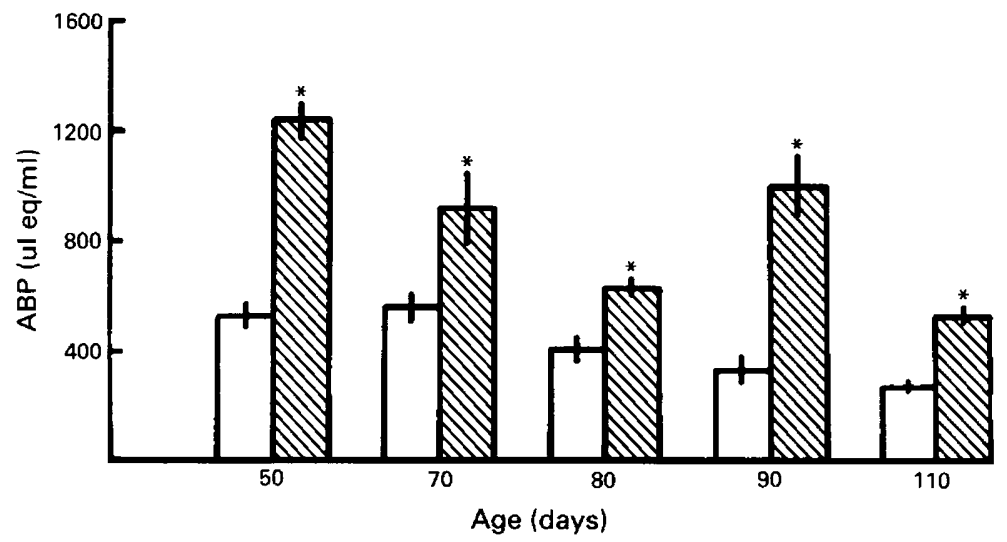

Fig. 2. Effects of vitamin A deficiency on serum ABP concentrations in control ( $\square$ ) and vitamin A-deficient $(\mathbb{N})$ rats. Values are mean \pm s.e.m. $\mathrm{N}=4$ rats per group. ${ }^{*} P<0.01$ compared with control values.

FSH binding. FSH binding to testicular tissue, expressed either pg per $\mathrm{mg}$ tissue or per $\mu \mathrm{g}$ protein, was not affected by vitamin A deficiency (Table 4).

cAMP production. The testicular cAMP response to FSH remained relatively stable throughout the time points studied and was not affected by the vitamin A status of the animals (Table 5). 
Table 3. Lactate concentrations $(\mu \mathrm{g} / \mathrm{ml})$ in seminiferous tubule fluid of control and vitamin A-deficient rats

\begin{tabular}{lccccccc}
\hline & \multicolumn{3}{c}{ Vitamin A-deficient rats } & & \multicolumn{3}{c}{ Control rats } \\
\cline { 2 - 3 } \cline { 7 - 8 } $\begin{array}{l}\text { Age } \\
\text { (days) }\end{array}$ & $\begin{array}{c}\text { No. of } \\
\text { rats }\end{array}$ & $\begin{array}{c}\text { Intact } \\
\text { testis }\end{array}$ & $\begin{array}{c}\text { EDL } \\
\text { testis }\end{array}$ & & $\begin{array}{c}\text { No. of } \\
\text { rats }\end{array}$ & $\begin{array}{c}\text { Intact } \\
\text { testis }\end{array}$ & $\begin{array}{c}\text { EDL } \\
\text { testis }\end{array}$ \\
\hline 50 & 4 & $324 \pm 14$ & $288 \pm 2$ & & 4 & $285 \pm 2$ & $235 \pm 11$ \\
70 & 4 & $392 \pm 44$ & $363 \pm 17$ & & 4 & $431 \pm 98$ & $410 \pm 36$ \\
80 & 4 & $259 \pm 9$ & $293 \pm 18$ & & 4 & $357 \pm 28$ & $336 \pm 20$ \\
90 & 4 & $301 \pm 26$ & - & & 4 & $265 \pm 15$ & $259 \pm 9$ \\
\hline
\end{tabular}

Values are mean \pm s.e.m.

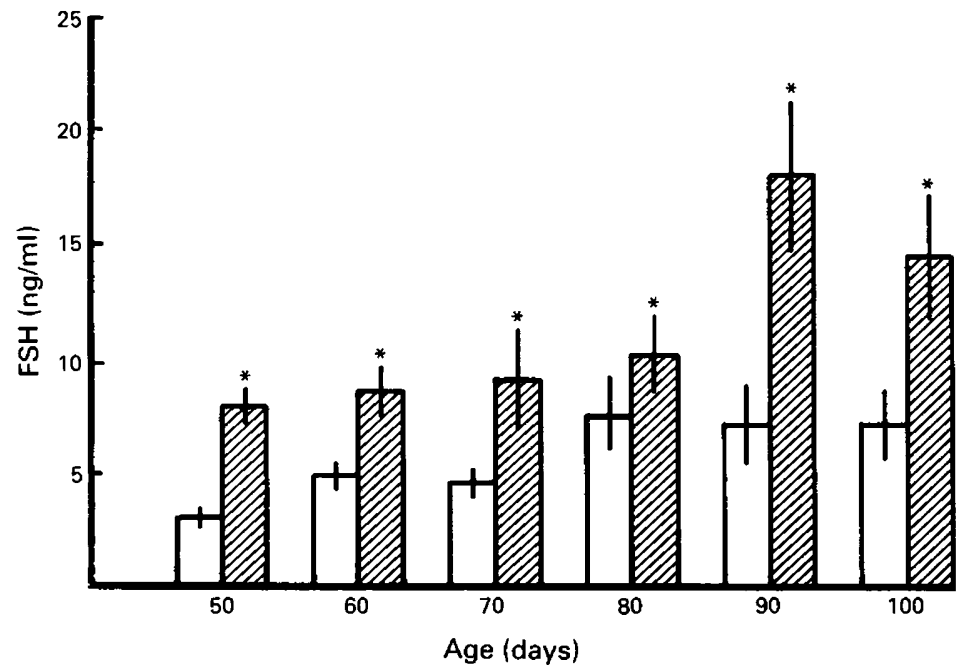

Fig. 3. Effect of vitamin A deficiency on serum FSH concentrations control ( $\square$ ) and vitamin A-deficient ( $/ / /$ ) rats with Sertoli cell enriched testes. Values are mean \pm s.e.m. $N=6-9$ rats per group. ${ }^{*} P<0.01$, compared with control values.

Table 4. FSH binding (pg) in Sertoli cell enriched testicular tissue of rats

\begin{tabular}{lcccccccc}
\hline & \multicolumn{3}{c}{ Vitamin A-deficient rats } & & \multicolumn{3}{c}{ Control rats } \\
\cline { 2 - 3 } \cline { 7 - 8 } $\begin{array}{l}\text { Age } \\
\text { (days) }\end{array}$ & $\begin{array}{c}\text { No. of } \\
\text { rats }\end{array}$ & $\begin{array}{c}\text { per mg } \\
\text { Tissue }\end{array}$ & $\begin{array}{c}\text { per } \mu \mathrm{g} \\
\text { Protein }\end{array}$ & & $\begin{array}{c}\text { No. of } \\
\text { rats }\end{array}$ & $\begin{array}{c}\text { per mg } \\
\text { Tissue }\end{array}$ & $\begin{array}{c}\text { per } \mu \mathrm{g} \\
\text { Protein }\end{array}$ \\
\hline 50 & 5 & $1704 \pm 107$ & $1045 \pm 136$ & & 4 & $1329 \pm 159$ & $840 \pm 125$ \\
60 & 6 & $2208 \pm 142$ & $1225 \pm 191$ & & 5 & $1822 \pm 257$ & $1580 \pm 116$ \\
70 & 6 & $2187 \pm 254$ & $1344 \pm 66$ & & 5 & $1335 \pm 95$ & $1043 \pm 108$ \\
80 & 6 & $1947 \pm 186$ & $1144 \pm 46$ & & 5 & $1721 \pm 168$ & $1365 \pm 162$ \\
100 & 6 & $2474 \pm 310$ & $1599 \pm 168$ & & 6 & $2226 \pm 136$ & $1196 \pm 162$ \\
\hline
\end{tabular}

Values are mean \pm s.e.m. 
Table 5. Cyclic AMP responses (pmol/g tissue) to FSH in Sertoli cell enriched testicular tissue of rats

\begin{tabular}{|c|c|c|c|c|c|c|}
\hline \multirow[b]{2}{*}{$\begin{array}{l}\text { Age } \\
\text { (days) }\end{array}$} & \multicolumn{3}{|c|}{ Vitamin A-deficient rats } & \multicolumn{3}{|c|}{ Control rats } \\
\hline & $\begin{array}{l}\text { No. of } \\
\text { rats }\end{array}$ & MIX & $\mathrm{MIX}+\mathrm{FSH}$ & $\begin{array}{l}\text { No. of } \\
\text { rats }\end{array}$ & MIX & $\mathrm{MIX}+\mathrm{FSH}$ \\
\hline 60 & 6 & $9.87 \pm 1.98$ & $12 \cdot 14 \pm 2.92$ & 5 & $10.83 \pm 4.44$ & $15.57 \pm 5.92$ \\
\hline 70 & 6 & $11 \cdot 34 \pm 4.69$ & $15.78 \pm 1.84$ & 5 & $10 \cdot 58 \pm 1 \cdot 14$ & $12.09 \pm 3.69$ \\
\hline 80 & 6 & $9 \cdot 68 \pm 0.89$ & $13.83 \pm 1.23$ & 5 & $10.57 \pm 0.70$ & $13 \cdot 79 \pm 1 \cdot 11$ \\
\hline 100 & 6 & $8.65 \pm 1.35$ & $12 \cdot 08 \pm 1 \cdot 34$ & 6 & $8 \cdot 28 \pm 2 \cdot 43$ & $12.47 \pm 1.81$ \\
\hline
\end{tabular}

Values are mean \pm s.e.m.

\section{Discussion}

The presence of cytosol retinol binding protein in Sertoli cells, but not in germ cells (Kato et al., 1985; Porter et al., 1985), suggests that retinol affects spermatogenesis through its actions on Sertoli cells. Since Sertoli cells are modulated by FSH which must bind to the Sertoli cell membrane to activate cellular functions (Means, 1975), modification of the Sertoli cell membrane during vitamin A-deficiency (Huang et al., 1988) may perturb normal FSH-Sertoli cell interactions and thereby worsen the functional status of Sertoli cells. However, because FSH-Sertoli cell interactions can be affected by germ cells (Parvinen, 1982), and the extent of germinal regression usually varied among rats with vitamin A deficiency (Huang et al., 1983), testicular tissues from regular vitamin Adeficient rats may not be appropriate for the evaluation of FSH-Sertoli cell interactions. However, although relatively insensitive to FSH in vivo, Sertoli cells from aged animals do respond to FSH in vitro (Heindel et al., 1982), and testicular tissue cAMP of rats with Sertoli cell enriched testes were also responsive to FSH in short-term culture (H. F. S. Huang \& S. Gould, unpublished data), we used rats with 'Sertoli cell-enriched' testes to examine the effects of vitamin A deficiency on the interactions between Sertoli cells and FSH.

The results of the present study demonstrated that in rats both FSH binding and the cAMP response to FSH in Sertoli cell-enriched testicular tissue were not affected by the vitamin A nutritional status of animals. The changes in Sertoli cell functions during vitamin A deficiency and subsequent degeneration of spermatogenesis were probably therefore unrelated to FSH-Sertoli cell interactions. This is different from those observed in cryptorchid testes in which FSH binding decreased (Hagenas \& Ritzen, 1976; Heindel et al., 1982; Jegou et al., 1983). However, since serum FSH concentrations of the vitamin A-deficient, Sertoli cell-enriched rats were elevated, the available FSH binding sites on Sertoli cell membranes may have been saturated and perhaps the adenylate cyclase system was stimulated fully. These conditions could mask the effects of vitamin A deficiency on the in-vitro assay of FSH-Sertoli cell interactions.

The presence of normal lactate concentrations in seminiferous tubular fluid of vitamin Adeficient rats indicates that Sertoli cells of these animals can metabolize glucose normally. Thus, the loss of germ cells during the early phase of vitamin A deficiency (Huang \& Marshall, 1983; Huang et al., 1983) was not caused by insufficient energy metabolism.

While significant reduction in testicular and epididymal ABP levels had been noted in aged vitamin A-deficient rats (Rich \& de Kretser, 1977; Huang et al., 1984), testicular ABP of such rats remained relatively normal at least until 110 days of age (Huang et al., 1984). These observations suggest that the production of testicular ABP in vitamin A-deficient rats may not be affected until a severe germinal regression became apparent. On the other hand, a transitory increase in epididymal $\mathrm{ABP}$ and the persistently higher serum ABP in vitamin A-deficient rats (Huang et al., 1984) suggest that the release ABP by Sertoli cells was affected by vitamin A status of the animals. 
In normal mature animals, ABP produced by Sertoli cells is primarily released into seminiferous tubules and transported to the epididymis (Gunsalus et al., 1980). Concomitantly, a small fraction of intracellular ABP enters the general circulation via interstitial space (Gunsalus et al., 1980). Since Sertoli-cell tight junctions may be important in the regulation of the bidirectional release of testicular ABP (Gunsalus et al., 1980), elevation of serum ABP in vitamin A-deficient rats (Huang et al., 1981, 1985) may result from higher ABP content in interstitial fluid due to leakage in Sertoli cell tight junctions, or increased permeability of the basement membrane of seminiferous tubules. To examine this hypothesis, we measured this protein in interstitial fluid and in seminiferous tubular fluid in rats at various stages of vitamin A deficiency.

The lack of a higher ABP concentration in the interstitial fluids of vitamin A-deficient rats indicates that the increased serum ABP concentrations in these rats was not due to an increase of ABP release through the seminiferous tubular wall. This is consistent with observations that Sertoli cell tight junctions of vitamin A-deficient rats remained intact at least until 80 days of age, the time that serum ABP was elevated (Huang et al., 1981, 1988). Although interstitial ABP concentrations of vitamin A-deficient rats aged 110 days were subnormal, total ABP in these fluids probably was higher due to the large volume of fluid collected. (In normal mature rats, the volume of interstitial fluid is $<100 \mu l$ per testis, while, due to severe oedema, it is $\geq 300 \mu \mathrm{l}$ per testis in 110-day-old vitamin A-deficient rats.) This apparent increase of total ABP in interstitial fluid may have contributed to some extent the higher serum ABP noted at this time.

The transitory increase of $\mathrm{ABP}$ in seminiferous tubular fluid in vitamin A-deficient rats occurred at the time when total testicular ABP content was normal (Huang et al., 1984), suggesting that a greater portion of intracellular ABP may have been released into seminiferous tubules. This occurred when serum and testicular retinol concentrations were at their nadir (Huang et al., 1988) but returned to normal after the rats were fed with supplementary retinoic acid. These observations demonstrate that both retinol and retinoic acid are capable of maintaining Sertoli cell ABP production and its release toward the apical direction, consistent with the results of in-vitro experiments (Mather et al., 1983). The transitory increase of ABP in seminiferous tubular fluid was apparently responsible for the higher epididymal ABP values in vitamin A-deficient rats noted previously (Huang et al., 1984).

The increased ABP concentrations in seminiferous tubular fluid after efferent duct ligation indicate the continuous release of this protein into seminiferous tubules. However, the percentage of this increment was lower in vitamin A-deficient rats suggesting that the rate of ABP secretion was reduced in these rats. A similar result was also noted by Rich \& de Kretser (1977). This phenomenon persisted throughout the experimental period and was not corrected after retinoic acid supplementation.

The present study demonstrates that, in rats, Sertoli cell secretory functions responded to the depletion of retinol differently. Since secretory functions represent the end results of numerous cellular activities, including cell membrane permeability, ionic fluxes and, perhaps, intracellular transport of various molecules, evaluation of each of these activities under various vitamin A states would be needed to elucidate the mechanisms responsible for vitamin A action on Sertoli cell secretory functions, as well as other aspects of Sertoli cell functions. This information may lead to understanding of the mechanisms which are responsible for the actions of vitamin $A$ on spermatogenesis.

We thank W. Giglio and Y. Lee for technical assistance, Mrs J. Cadogan and Mrs C. Davis for secretarial assistance; and Mr G. Govelitz of the Department of Radiology, NJMS, for the Xirradia'ion of pregnant female rats. The rFSH and rABP assay kits were kindly provided by NIAD, K, NIH.

This study was supported by a grant from Foundation of University of Medicine and Dentistry of New Jersey, and a Merit Grant from Veterans Administration, U.S.A. 


\section{References}

Gunsalus, G.L., Musto, N.A. \& Bardin, C.W. (1978) Immunoassay of androgen binding protein in blood: a new approach for study of the seminiferous tubules. Science, N.Y. 200, 65-66.

Gunsalus, G.L., Musto, N.A. \& Bardin, C.W. (1980) Bidirectional release of a Sertoli cell product, androgen binding protein, into the blood and seminiferous tubule. In Testicular Development, Structure and Function, pp. 291-297. Eds A. Steinberger \& E. Steinberger. Raven Press, New York.

Hagenas, L. \& Ritzen, E.M. (1976) Impaired Sertoli cell function in experimental cryptorchidism in the rat. Molec. cell. Endocrinol. 4, 25-34.

Heindel, J.J., Berkowitz, A., Steinberger, A. \& Strada, S.J. (1982) Modification of Sertoli cell responsiveness to FSH by cryptorchidism and hypophysectomy in immature and adult rats. $J$. Androl 3, 337-343.

Huang, H.F.S. \& Hembree, W.C. (1979) Spermatogenic response to vitamin $\mathrm{A}$ in vitamin $\mathrm{A}$ deficient rats. Biol. Reprod. 21, 891-904.

Huang, H.F.S. \& Marshall, G.R. (1983) Failure of spermatid release under various vitamin A states-an indication of delayed spermiation. Biol. Reprod. $\mathbf{2 8}$, $1163-1172$

Huang, H.F.S., Smith, J.E., Gunsalus, G.L. \& Hembree, W.C. (1981) Chronology of testicular effects of vitamin A deficiency (VAD) upon male rats. Endocrinology (Suppl.), 108, Abstr. 1063.

Huang, H.F.S., Dyrenfurth, I. \& Hembree, W.C. (1983) Endocrine changes associated with germ cell loss during vitamin A deficiency and vitamin A-induced recovery of spermatogenesis. Endocrinology 112 , 1163-1171.

Huang, H.F.S., Boccabella, A.V. \& Gunsalus, G.L. (1984) Leaking Sertoli cell tight junctions in vitamin A deficient rats. In International Cell Biology 1984 Abstr. 2107. Eds S. Seno \& Y. Okada. Academic Press Japan Inc., Tokyo.

Huang, H.F.S., Dyrenfurth, I., Gunsalus, G.L., Hembree, W.C. (1985) Effect of vitamin A deficiency upon gonadotropin response to gonadotropin-releasing hormone. Biol. Reprod. 33, 1177-1187.

Huang, H.F.S., Yang, C.S., Meyenhofer, M., Gould, S. \& Boccabella, A.V. (1988) Disruption of sustentacular (Sertoli) cell tight junctions and regression of spermatogenesis in vitamin A deficient rats. Acta anat. (In press).

Jegou, B., Risbridger, G.P. \& de Kretser, D.M. (1983) Effects of experimental cryptorchidism on testicular function in adult rats. $J$. Androl. 4, 88-94.

Kato, M., Sung, W.K., Kato, K. \& Goodman, D.S. (1985) Immunohistochemical studies on the localization of cellular retinol binding protein in rat testis and epididymis. Biol. Reprod. 32, 173-189.
Lowry, O.R., Rosebrough, N.J. Farr, A.L. \& Randall, R.J. (1951) Protein measurement with the Folin phenol reagent. J. biol. Chem. 193, 265-275.

Mather, J.P., Gunsalus, G.L., Musto, N.A., Cheng, C.Y., Parvinen, M., Wright, W., Perez-Infante, V., Margiorist, A., Liotta, T., Becker, R., Krieger, D.T. \& Bardin, C.W. (1983) The hormonal and cellular control of Sertoli cell secretion. J. Steroid Biochem. 19, 41-51.

Means, A.R. (1975) Biochemical effects of follicle stimulating hormone on the testis. In Handbook of Physiology, Sec. 7. Endocrinology, Vol. V: Male Reproductive System, pp. 203-218. Eds D. W. Hamilton \& R. O. Greep. American Physiological Society, Washington, D.C.

Means, A.R., Fakunding, J.L., Huckins, C., Tindall, D.J. \& Vitale, R. (1976) Follicle-stimulating hormone, the Sertoli cell and spermatogenesis. Recent Prog. Hormone Res. 32, 477-527.

Miyachi, Y., Vaitukaitis, J.L., Nieschlag, E. \& Lipsett, M.B. (1972) Enzymatic radioiodination of gonadotropin. J. clin. Endocr. Metab. 34, $23-28$.

Parvinen, M. (1982) Regulation of the seminiferous epithelium. Endocrine Rev. 3, 404417.

Porter, S., Ong, D., Chytil, F. \& Orgebin-Crist, M.C. (1985) Localization of cellular retinol-binding and cellular retinoic acid binding protein in the rat testis and epididymis. J. Androl. 6, 197-212.

Rich, K.A. \& de Kretser, D.M. (1977) Effect of differing degrees of destruction of the rat seminiferous epithelium on levels of serum follicle stimulating hormone and androgen binding protein. Endocrinology 101, 959-968.

Setchell, B.P. \& Waites, G.M.H. (1975) The blood testis barrier. In Handbook of Physiology, Sect. 7. Endocrinology, Vol. V: Male Reproductive System, pp. 143-172. Eds D. W. Hamilton \& R. O. Greep. American Physiological Society, Washington, D.C.

Thompson, J.N., Howell, J. McC. \& Pitt, G.A. (1964) Vitamin $A$ and reproduction in rats. Proc. $R$. Soc. $B$ 159, 510-535.

Turner, T.T., Jones, C.E., Howards, S.S., Ewing, L.L., Zageye, B. \& Gunsalus, G.L. (1984) On the androgen microenvironment of maturing spermatozoa. Endocrinology 115, 1925-1932.

Unni, E., Rao, M.R. \& Ganguly, J. (1983) Histological and ultra-structural studies on the effect of vitamin $A$ depletion and subsequent repletion with vitamin $\mathbf{A}$ on germ cells and Sertoli cells in rat testes. Ind. J. exp. Biol. 21, 180-192.

Received 13 June 1988 